Cesar José Grupi, Paulo Jorge Moffa, Silvio Alves Barbosa, Paulo César Sanches, Enivam G. Barragan Filho, Giovanni M. V. Bellotti, Fúlvio José Carlos Pileggi

\title{
Holter monitoring in Chagas' heart disease
}

\author{
Heart Institute, Hospital das Clínicas da Faculdade de Medicina \\ da Universidade de São Paulo - São Paulo, Brazil
}

\begin{abstract}
Electrocardiographic rythm disturbance evaluation by Holter monitoring is increasingly becoming a useful methodologic tool for risk stratification as well as for therapeutic assessment in patients with Chagas' desease. Furthermore, late potential analyses, now being directly obtained from Holter recording has promising perspectives in enhancing identification of patients with high risk profiles for development of malignant ventricular arrhythmias. In addition, recently incorporated to Holter studies, heart rate variability analysis will certainly contribute to a better understanding of the characteristic autonomic nervous system disarray that commonly affects chagasic patients.
\end{abstract}

UNITERMS: Chagas disease. Holter monitoring.

\section{INTRODUCTION}

$\mathrm{T}$ he possibility of continuously recording the electrocardiogram (ECG) over long periods of time and its subsequent rapid analysis, currently using automatic computerized processes, was introduced to clinical practice by Norman Holter in 1961(19). This

\author{
Address for correspondence: \\ Cesar José Grupi \\ Divisão de Métodos Gráficos (Serviço de Holter) \\ Instituto do Coração - Hospital das Clínicas da FMUSP \\ Av. Dr. Enéas de Carvalho Aguiar, 44 \\ Sáo Paulo - SP - Brasil - CEP 05403-000
}

instrumental practice allowed normally transitory electrocardiographic alterations of specific populations, carriers or not $(4,30)$ of different cardiopathies $(6,40)$, to be recognized and related to the prognosis. In this way groups of patients with Chagas' disease were also observed $(27,38)$.

It is known that one of the principal limitations of the conventional ECG is its short time of observation. With Holter's method, there is a great increase in the capacity to detect intermittent alterations, with an observation of 24 hours showing the best cost/benefit ratio (3). Its utility in Chagas' disease was evaluated by Maguire (26) (among others), where $80 \%$ of the patients that demonstrated a normal conventional ECG reading were revealed to have ventricular extrasystoles, with an average of $1 /$ hour and $6.7 \%$ of pairs or volleys in the Holter method. In the case 
of conventional ECG with ventricular extrasystoles, their presence was confirmed with the Holter method in all patients, with a density of $290 /$ hour and $88 \%$ of the cases with pairs or volleys. This same author, comparing between the different electrocardiographic methods - conventional ECG, exercise ECG, and Holter's method -, also demonstrated that the latter was the only one capable of identifying most patients with arrhythmias, including those with the most severe forms (27).

It should be remembered that this method gives information about transitory and spontaneous electrocardiographic events only during the period of examination, usually 24 hours. Often certain types of arrhythmias, sometimes severe ones, are not registered due to their non-occurrence during the time of recording. Because of this, depending on what one is trying to document, the time of study may be extended, either sequentially or intermittently. In groups of patients without apparent cardiopathy, arrhythmias and/or transitory disturbances of the atrioventricular conduction are also observed which, in spite of the lesser per-hour frequency, could show up in a repetitive manner (pairs and nonsustained ventricular tachycardia) $(6,40)$, with a similar prognosis to those without arrhythmia (21). These findings demonstrate that the prognosis of isolated findings of arrhythmia in prolonged ECG observations is also dependent upon other factors, such as: degree of ventricular dysfunction (4), aneurysmatic alterations of the left ventricle (9), and automatic imbalance (8). As has already been commented in other articles in this edition, from the clinical point of view, Chagas' disease demonstrates two forms:

a) Acute form

b) Chronic form

1) indeterminate

2) digestive

3) cardiac

In this revision we will only deal with the chronic and indeterminate forms.

\section{INDETERMINATE FORM}

The silent specific infection, showing a normal conventional ECG reading, and normal radiographs of the thorax, stomach and colon, is considered the indeterminate form. However, when studying such cases with more refined methods, invasive or non-invasive, many patients already exhibit cardiac alterations $(25,29,33)$.
In the publications consulted $(10,18,27,29,33)$, a similarity can be observed with regard to individuals without cardiopathy, with regard to the incidence of ventricular extrasystoles, the number of ventricular extrasystoles/hour and complexity, except in the rare cases where frequent $(>30 / \mathrm{h})(29)$ ventricular extrasystoles were observed. However, it is not known if this last finding relates to a greater degree of cardiac compromise or unfavorable evolution, in relation to those where arrhythmia was not observed or was rare.

The same happened for atrial extrasystoles, sinus pauses, and second degree type I atrioventricular blockages, these last two alterations occurring rarely.

As already noted, one of the clinical characteristics of this group is silent and prolonged evolution. Nevertheless, some of the cardiac alterations identified with invasive methods show a high risk potential (2). Thus, even without having conclusive information, the finding of potentially malignant arrhythmias points to an amplification of the investigation of possible cardiac compromise, besides the introduction of therapeutic procedures, if necessary. On the other hand, the absence of arrhythmias of risk could serve as a favorable medical argument in cases where an employer is refusing to admit individuals with positive serologic tests, in this way avoiding the underemployment of large numbers of productive individuals (10).

\section{CHRONIC FORM}

The anatomical substrate of chronic chagasic cardiopathy is chronic fibrous myocarditis, progressive and diffuse, that gradually destroys the myocardial fibers, not just the muscular fibers but also those of the sinusal node and conduction tissue. Besides this, the aggression against the ganglion and the nerve endings (23) produces modifications in the automatic response (28). Thus, chronic chagasic cardiopathy produces the lesions necessary for the development of various electrocardiographic disturbances, principally cardiac arrhythmias, either persistent or transitory (9).

The electrocardiographic alterations most frequently found in chronic Chagasic cardiopathy are right bundlebranch block, anterosuperior division block, negative $\mathrm{T}$ wave, and ventricular systoles $(35,39)$. The bathmodromotropic alterations of greatest prognostic importance are fibrillation and atrial flutter, total atrioventricular block, complete left bundle-branch block, 
frequent and polymorphic ventricular extrasystoles, ventricular tachycardias and alterations suggestive of fibrous necrosis, besides anomalies of the S-T segment and the $\mathrm{T}$ wave. The association of two or more alterations worsens the prognosis (37). Besides this, according to the observations of various authors, cardiomegaly associated with the symptoms of congestive cardiac insufficiency would have a worse prognosis than those with electrocardiographic alterations only $(5,7,12,37)$.

Guerrero (17) et al., comparing patients with chagasic cardiopathy and other myocardiopathies, demonstrated that the degree of ventricular dysfunction was the most important independent prognostic factor. Complex ventricular arrhythmia has additional limited importance in patients with depressed diastolic function of the left ventricle.

The occurrence of arrhythmias, in terms of frequency/ hour and repetitiveness, increases proportionally with the degree of cardiac compromise verified by conventional electrocardiogram.

They are less frequent in patients with the chronic form with minimum ECG alterations and more frequent and repetitive when the patient demonstrates bundlebranch block and ventricular extrasystoles $(7,10,17,27,37)$.

A relationship between frequency and complexity of ventricular arrhythmia and the degree of dysfunction of the left ventricle was observed by Santana (37) and Carrasco (7). The former calls attention because of its greater incidence in age groups under (20), which differs significantly from those individuals without cardiopathy (40).
In Chagas' disease, as in other cardiopathies, ventricular arrhythmia presents great variability, which should be taken into account in population evaluations as well as in therapeutic control. According to our observations, the number of ventricular extrasystoles/hour has a circadian character and tends to be related to variations of cardiac frequency per hour. The same patient shows a variation of $58.4 \%$ in the number of ventricular extrasystoles/hour when we compare 2 consecutive 21 hour duration recordings. In shorter recordings, the variation is so great that it doesn't even allow comparison (7).

With regard to the other arrhythmias, sinus pauses, atrial extrasystoles and atrioventricular blocks are less commonly cited in the literature, probably because of their lesser clinical importance, even though their pattern of distribution is similar to that of ventricular extrasystoles $(10,24)$.

The relationship between symptoms and ventricular arrhythmia observed through Holter's method was studied by Mendonça (31) and Rassi Jr. (34), who noted a significantly greater number of ventricular extrasystoles in patients with symptoms of syncope and near-syncope.

In Brazil, chagasic cardiopathy constitutes one of the most frequent cause for the indication of artificial pacemaker implants. Holter's method is one of the principal tools used, both to confirm the necessity of the procedure and to determine the type of stimulation needed, as well as to follow-up the patient after the implant. In the follow-up after the implant its utility ranges from clarification of symptoms, which could be due to faulty

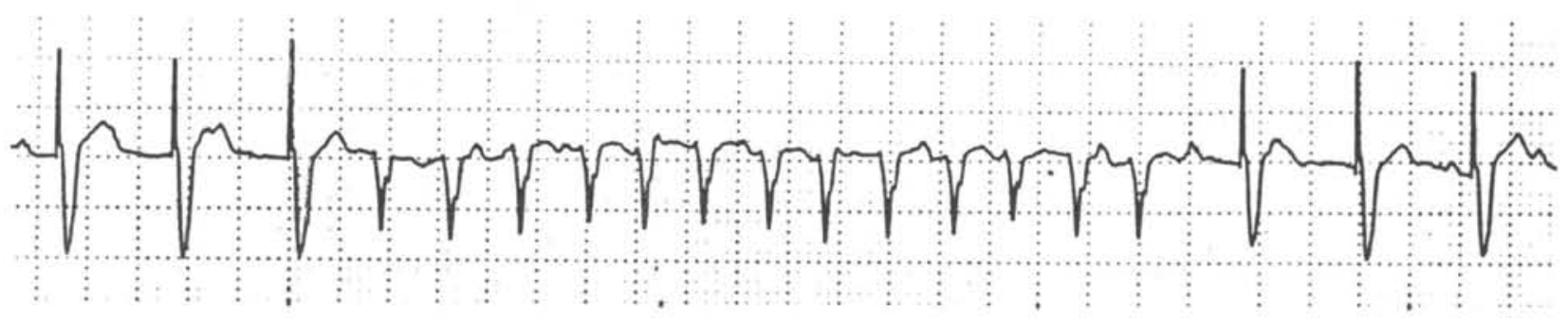

Figure 1 - Tracing of a subject with an artificial ventricular pacemaker. The pacemaker was placed in the subject who had syncope attacks because of episodes of complete atrio-ventricular block of Chagasic nature. The subject presented a non-sustained ventricular tachycardia with 13 beats during Holter testing (CM5 lead). 
functioning of the stimulation system as well as to periods of ventricular tachycardia (14) to orientation for better programming. It is also very effective for identification of intermittent defects. Normally the latter are not diagnosed during a conventional electronic evaluation (for example, intermittent loss of command, microfractures in the electrodes, increases in the stimulation threshold, external interference etc.) (Fig.1).

Various tests of automatic function have already been applied on patients with chronic chagasic cardiopathy (28). Currently it is possible to study the variability of cardiac frequency with Holter recordings. This technique allows evaluation of the automatic activity of the sinus node and has been used as an indicator of risk in patients with coronary disease (22), and as an early warning of visceral neuropathy in diabetics (11). As of yet, we don't have data about its prognostic importance for patients with Chagas' disease.

Technological advances have permitted the incorporation of new techniques into the Holter method. One of them is its utilization for obtaining high resolution electrocardiograms. Already well established as a method for evaluation of risk in patients with coronary disease, being capable of identifying those with the possibility of developing ventricular tachycardial crisis and sudden death (13), it has also been useful with Chagas' disease (32). Nevertheless, the evaluation of Chagas' disease using Holter's method is still in the development phase (20).

\section{Resumo}

A utilização do método de Holter na Doença de Chagas tem permitido melhor conhecimento das suas anormalidades elétricas, do comportamento das alteraçōes eletrocardiográficas transitórias, colaborando no estabelecimento do grau de risco e no controle de procedimentos terapêuticos. A introdução de novas tecnologias ao método como a análise da variabilidade da frequêencia cardiaca com possibilidade de avaliar a atividade autonômica sobre o nó sinusal poderá permitir avaliaçāo nāo invasiva deste aspecto tão importante da doença. A possibilidade da aquisição do eletrocardiograma de alta resoluçāo a partir de gravaçōes de Holter poderá ampliar a avaliação do risco destes pacientes. 
1. ANDRADE, Z.A. \& ANDRADE, S.G. - Patologia. In: Brener $\mathrm{Z}$ e Andrade AA, eds. Trypanosoma Cruzi e Doença de Chagas. Rio de Janeiro, Guanabara Koogan, 1979. p. 199248.

2. BENCHIMOL, C.G.; BARBOSA FILHO, J.; LOPES, A.S.; LOPES, J.S.; SOARES, J.P.; BENCHIMOL, A.B. - Avaliação hemodinâmica e cineangiográfica do ventrículo esquerdo em 28 pacientes com Doença de Chagas. Arq Bras Cardiol 37:168, 1981.

3. BIGGER, J.T.; ROLNITZKY, L.M.; LEAHEY, E.B. \& LAPOOK, J.D. - Duration of recording; activity protocol. In: Wenger NK, Nock MB and Ringquist I. Chicago, Year Book Medical Publishers Inc, 1981, p. 87-102.

4. BIGGER, T.; FLEISS, J.L.; KLEIGER, R.; MILLER, J.P.; ROLNITZKY, L.M. and The Multicenter Pos-Infarction Research Group - The relationships among ventricular arrhythmias, feft ventricular dysfunction, and mortality 2 years after myocardial infarction. Circulation 69:250-8, 1984.

5. BRASIL, A. - Evolução e prognóstico da Doença de Chagas. Arq Bras Cardiol 18:365-80, 1965.

6. BRODSKY, M.; WY, D.; DENES, P.; KONAKIS, C. \& ROSEN, K.M. - Arrhythmias documented by 24 hours continous electrocardiographic monitoring in 50 male medical students witout apparent heart disease. Am J Cardiol 39:390-7, 1977.

7. CARRASCO, H.A.; GUERRERO, L.; PARADA, H.; MOLINA, C.; VEGAS, E. \& CHUECOS, R. - Ventricular arrhythmias and left ventricular myocardial function in chronic chagasic patients. Int J Cardiol 28:35-41, 1990.

8. COUMEL, P. - The management of clinical arrhytmias. An overview on invasive versus non-invasive electrophysiology. Eur Heart J 8:92-9, 1987.

9. DE PAOLA, A.A.; HOROWITZ, L.N.; MIYAMOTO, M.H. et al. - Angiographic and electrophysiologic substrates of ventricular tachycardia in chronic chagasic miocarditis. Am J Cardiol 65:360-3, 1990.

10. ELUF NETO, J. - Doença de Chagas em área urbana: avaliação de função cardíaca de trabalhadores industriais e implicações para a atividade laboral. São Paulo, 1985; 164 p. [Dissertação de Mestrado - Universidade de São Paulo].

11. EWING, D.J.; MARTYN, C.N.; YOUNG, R.J. et al. - The value of cardiovascular autonomic function test: 10 years experiences in diabetes. Diabetes Care 8: 491-7, 1985.

12. FREITAS, H.F.G.; SOSA, E.A.; SCANAVACCA, M. \& BELOTTI PILEGGI, F. - Valor prognóstico da arritmia ventricular freqüente e/ou complexa na cardiopatia chagásica crônica. Arq Bras Cardiol 49:46, 1988.

13. GOMES, J.A.; WINTERS, S.I.; MARTINSOU, M.; MACHAC, J.; STEWART, D. \& TARGONSKI, A. - The prognostic significance of quantitative signal-averaged variables relative to clinical variables, site of myocardial

infarction, ejection fraction and ventricular premature beats; a prospective study. J Am Cardiol 13: 377-84, 1989.

14. GOOD GOD, E.M.; MAGNANI, F.L. \& LEITE, R.C. Arritmia ventricular sintomática (análise clínica - ECG dinâmico) no cardiopata chagásico com marcapasso cardíaco. Arq Bras Cardiol 59:23, 1992.

15. GRUPI, C.; PILEGGI SOSA, E. et al. - Eletrocardiograma do Feixe de His (EFH)-Estudo da condução atrio-ventricular (A.V.) com estimulação atrial em pacientes sem cardiomiopatia c/ Machado Guerreiro positivo. Arq. Bras. Cardiol. 29: 234, 1976.

16. GRUPI, C.J.; SOSA, E.A.; CARVALHO, J.F.; ANTONELLI, R.H.; BELLOTTI, G. \& PILEGGI, F. - Variabilidade espontânea da extrasistolia ventricular na cardiopatia chagasica crônica. Arq Bras Cardiol 56:445-50, 1991.

17. GUERRERO, L.; CARRASCO, H.; PARADA, H.; MOLINA, C. \& CHUECOS, R. - Mecânica ventricular e arritmias cardíacas em pacientes chagásicos e com miocardiopatias dilatadas primárias. Seguimento ecoeletrocardiográfico. Arq Bras Cardiol 56:465-9, 1991.

18. HASSEN S ${ }^{\circ}$, S.; LORGA, A.M.; BELLINI, A.J. et al. - Holter de 24 horas em chagásicos crônicos com ECG convencional normal Arq Bras Cardiol 43:99, 1985.

19. HOLTER, N.J. - New method for heart studies. Science 134:1214-20, 1961.

20. KELEN, G.; HENKINS, R.; LANNON, M.; BLOOMFIELD, D. \& EL-SHERIF, N. - Correlation between the signalaveraged electrocardiogram from Holter tapes and real-time recordings. Am J Cardiol 63: 1321-5, 1989.

21. KENNEDY, H.L.; WHITLOCK, J.A.; SPRAGUE, M.K.; KENNEDY, L.J.; BUCKINGHAM, T.A. \& GOLDBERG, R.J. - Long-term follow-up of asymptomatic healthy subjects with frequent and complex ventricular ectopy. $\mathbf{N}$ Engl J Med 312:193-7, 1985.

22. KLEIGER, R.E.; MILLER, J.P.; BIGGER, J.T. et al Decreased heart variability and its association with increased mortality after acute myocardial infarction. Am J Cardiol 59: 256-303, 1987.

23. KÖBERLE, F. - Cardiopatia Chagásica. Hospital (Rio de Janeiro) $53: 311-46,1958$.

24. KUSCHNIR, E.; SGAMMINI, H.; EVEQUOZ, C. \& BRUNETTO, J. - Prevalência de las alteraciones de la función del nodulo sinusal en cardiopatia chagásica cronica. Implicancias terapeuticas. Arq Bras Cardiol 43:136, 1985.

25. KUSCHNIR, E.; VERA, T.; NOTA, C. et al. - Valoracion de arritmias, parte II: Holter de 24 hs en pacientes chagásicos grupo "0" y sujetos normales. Arq Bras Cardiol 41:72, 1983.

26. MAGUIRE, J.H.; RAMOS, N.B.; SANTANA, O.O.; ALMEIDA, E.C. \& GUIMARÃES, A.C. - Comparação do eletrocardiograma convencional com o eletrocardiograma dinâmico na avaliação das arritmias na Doença de Chagas. Arq Bras Cardiol 37:82, 1981.

27. MAGUIRE, J.H.; RAMOS, N.B.; SANTANA, O.O.; ALMEIDA, E.C. \& GUIMARÃES, A.C. - Sensibilidade de métodos na detecção de arritmias ventriculares na Doença de Chagas. Arq Bras Cardiol 37:82, 1981. 
28. MANÇO, J.C.L.; GALLO JR., L.; MARINE NETO, J.A.; TERRA FO., J.; MACIEL, B.C. \& AMORIM, DS. Alterações Funcionais do sistema nervoso autônomo. In: Cançado, J.R. e Chuster, M., eds. Cardiopatia Chagásica. Belo Horizonte, I. Oficial, 1985. p.91-8.

29. MARINS, N.; MARTINS, A.; MIRANDA, L.; SEIXAS, T. \& LOBO E FLORES, A. - Eletrocardiografia dinâmica de 24 horas em chagásicos na forma indeterminada. Arq Bras Cardiol 43:122, 1984.

30. MEINERTZ, T.; HOFMANN, T.; KASPER, W. et al. Significance of ventricular arrhythmias in idiopathic dilated cardiomyopathy. Am J Cardiol 53:902-7, 1984.

31. MENDONÇA, A.; DE PAOLA, A.A.V.; SILVA NETO, O. et al. - Monitorização eletrocardiogáfica em pacientes com cardiopatia chagásica crônica e fenômenos sincopais. Arq Bras Cardiol 59:182, 1992.

32. MORAES, A.P. - O eletrocardiograma de alta resolução na Cardiopatia Chagásica Crônica. São Paulo, 1993; 75 p. [Tese de Doutoramento - Universidade de São Paulo].

33. PEREIRA BARRETO, A.C.; BELLOTTI, G.; SOSA, E. et al. - Arritmias e a forma inderteminada da Doença de Chagas. Arq Bras Cardiol 47:197-9, 1986.

34. RASSI JR.; RASSI, A.G.; RASSI, S.G. RASSI, JR., L. \& RASSI, A. - Relação entre sintomas, disfunção ventricular e arritmia ventricular na cardiopatia chagásica crônica. Arq Bras Cardiol 59:182, 1992.
35. ROSENBAUN, M.B. \& ALVAREZ, A.J. - The electrocardiogram in chronic chagasic myocarditis. Am Heart J 50:492-503, 1955.

36. RUBERMAN, W.; WEINBLATT, E.; GOLDBERG, J.D.; FRANK, C.W.; CHAUDHARY, B.S. \& SHAPIRO, S. Ventricular premature complexes and sudden death after myocadial infarction. Circulation 64:297-301, 1981.

37. SANTANA, O.O. - Arritmia ventricular e evolução clínica de pacientes na fase crônica da Doença de Chagas. Salvador, Bahia, 1987; 50 p. [Dissertação de Mestrado Universidade Federal da Bahia].

38. SGAMINI, H.; KUSCHNIR, E.; EVEQUECZ, C.; NOTA, C. \& VERA, T. - Caracterización de arritmias ventriculares em cardiopatia chagasica cronica con Holter. Arq Bras Cardiol 45:128, 1985.

39. TRANCHESI JR., B.; ARTEAGA-FERNÁNDEZ, E.; PEREIRA BARRETO, A.C. et al. - O eletrocardiograma na forma crônica da Doença de Chagas. Estudo de 400 casos. Arq Bras Cardiol 39:31, 1981.

40. WAJNGARTEN, M.; GRUPI, C.; BELLOTTI, G.M.; DA LUZ, P.L.; SERRO AZUL, L.G. \& PILEGGI, F. - Frequency and significance of cardiac rhythm disturbances in healthy elderly individuals. J. Electrocardiol 23:171-6, 1990. 